\title{
PENGARUH CUSTOMER RELATIONSHIP MANAGEMENT (CRM), CUSTOMER VALUE SERTA KEPERCAYAAN TERHADAP LOYALITAS KEPUASAN NASABAH
}

\section{THE EFFECT OF CUSTOMER RELATIONSHIP MANAGEMENT (CRM), CUSTOMER VALUE AND TRUST ON CUSTOMER SATISFACTION LOYALTY}

\author{
Imam Fatoni ${ }^{1}$, Nyoman Sockarini ${ }^{2}$ \\ Universitas Moch Sroedji Jember ${ }^{1,2}$ \\ fatoniums12@gmail.com ${ }^{1}$
}

Submit, 22-02-2019 Accepted,30-04-2019 Publish,03-05-2019

\begin{abstract}
Customer satisfaction can be a determining factor in increasing customer purchases of a product and service. This study aims to determine the effect of variable customer relationship management, customer value, trust and customer satisfaction on customer loyalty PT.Adira Finance Jember. The data used in this study is primary data. Data processing method uses path analysis method with the help of SPSS 24 analysis tools.. The results showed that the variable customer relationship management, customer value, trust and customer satisfaction influence the customer loyalty of PT.Adira Finance Jember either directly or indirectly
\end{abstract}

Keywords: CRM, Customer Value, Trust, Customer Satisfaction, Customer Loyalty

\begin{abstract}
ABSTRAK
Kepuasan nasabah dapat merupakan faktor penentu dalam peningkatan pembelian pelanggan terhadap suatu produk dan jasa. Penelitian ini bertujuan untuk mengetahui pengaruh Variabel customer relationship management, Customer value, Kepercayaan serta kepuasan nasabah terhadap PT.Adira Finance Jember Data yang digunakan berupa data primer. Metode pengolahan data menggunakan metode analisis jalur dengan bantuan alat analisis SPSS 24. Hasil penelitian menunjukkan bahwa Variabel customer relationship management, Customer value, Kepercayaan serta kepuasan nasabah berpengaruh terhadap loyalitas nasabah PT.Adira Finance Jember baik secara langsung ataupun tidak langsung
\end{abstract}

Kata Kunci: CRM, Customer Value, Kepercayaan, Kepuasan Nasabah, Loyalitas Nasabah

\section{PENDAHULUAN}

Kepuasan nasabah terhadap PT. Adira Finance merupakan hasil kinerja perusahaan dalam keberhasilannya sesuai keinginanan yang di capai, tidak hanya dalam jangka pendek, tetapi dipergunakan untuk keunggulan persaingan di masa yang akan datang .
Hal ini karena kepuasan nasabah memiliki nilai strategis bagi perusahaan, bagi perusahaan lain seperti halnya IBM, Cola, Singapore Airlines, Xerox, dan sejumlah merek lain tidak terlepas dari ikatan yang kuat dari nasabahnya, yaitu suatu bentuk kepuasan yg di dapat oleh nasabahnya. 
Kepuasan nasabah dapat menentukan peningkatan pembelian terhadap PT. Adira Finance, bentuk nilai kepuasan nasabah merupakan ukuran kedekatan nasabah pada sebuah jenis merk tertentu, , sebuah merek atau jenis produk menjadi top of mind (merek pertama yang muncul) jika mengingat sebuah kategori produk, komitmen merek yang mendalam dan dapat memaksa preferensi pilihan untuk melakukan pembelian, serta membantu nasabah mengindentifikasi suatu perbedaan mutu terhadap nilai produk lainnya. Argumentasi ini memperkuat dan menjadi penting bagi perusahaan agar kepercayaan atas suatu nilai barang atau merk tertentu dapat menjadi tingkat kepuasan terhadap konsumennya.

Loyalitas kepuasan nasabah merupakan perilaku yang terkait dengan sebuah produk, yang kemungkinkan akan memperbarui pembelian jenis merk yang sama di masa yang akan datang. Adapun kemungkinan nasabah mengubah pilihannya terhadap merek tertentu, hal ini dilakukan oleh nasabah untuk meningkatkan citra positif suatu produk.

Salah satu cara yang dilakukan untuk mengetahui tingkat kepuasan adalah dengan customer relationship management. CRM yaitu usaha sebuah perusahaan untuk berkonsentrasi menjaga pelanggan dengan mengumpulkan segala bentuk interaks. Management (CRM) dalam Meningkatkan loyalitas Pelanggan mail, masukan di situs atau hasil pembicaraan dengan staf penjualan dan pemasaran melalui sarana telekomunikasi melalui telpon. Hal ini dapat diartikan sebagai sebuah bentuk strategi bisnis dalam suatu perusahaan yang memungkinkan perusahaan tersebut secara efektif bisa mengelola hubungan dengan para pelanggan.
Perusahaan dapat tetap unggul dan bersaing dengan menciptakan tingkat kepuasan konsumen yang tinggi dibandingkan pesaingnya secara konsisten, selain itu perusahaan juga dapat menciptakan suatu sistem untuk memperoleh pelanggan yang lebih banyak dan kemampuan untuk menghasilkan nilai kepuasan terhadap konsumennya, serta menjaga tingkat kepercayaan konsumen pada perusahaan.

Studi empiris yang dilakukan Nardiman (2017) dengan judul Pengaruh Customer Relationship Management Dan Customer Value Terhadap Kepuasan Nasabah dan Implikasinaya pada Loyalitas Nasabah Bank BRI Unit menyimpulkan bahwa 1) Customer Relationship Management berpengaruh signifikan terhadap kepuasan nasabah Bank BRI Unit . Semakin baik customer Relationship Management tentunya akan meningkatkan bentuk kepuasan nasabah bank tersebut. Artinya apabila hubungan terhadap nasabah terjalin dengan baik maka akan memberikan pengaruh positif terhadap kepuasan nasabah. 2) Customer Value berpengaruh signifikan terhadap kepuasan nasabahnya. Artinya apabila customer value dapat memberikan pengaruh positif terhadap kepuasan nasabah. 3) Customer Relationship Management berpengaruh signifikan terhadap loyalitas kepuasaan para nasabah Bank BRI Unit. Semakin baik customer Relationship Management tentunya akan meningkatkan kepuasaan nasabah. Artinya apabila hubungan dengan nasabah terjalin dengan baik tentunya akan memberikan pengaruh positif terhadap loyalitas kepuasan nasabah

PT.Adira Finance. berdiri pada bulan Maret 1990, yang beralamat di Graha Adira jalan Menteng Jakarta 
Selatan. PT. Adira Dinamika Multi Finance Tbk. selalu berkembang dari tahun ke tahun, dan pada tahun 2004 PT. Bank Danamon bergabung sebagai pemilik saham.

Perkembangan perusahaan PT. Adira Finance cukup pesat hingga sekarang dan memiliki cabang hampir di seluruh wilayah Indonesia. Ini menunjukan bahwa tingkat Kebutuhan masyarakat terhadap kendaraan bermotor baik roda dua maupun roda empat meningkat, serta belum adanya perusahaan pesaing merupakam menjadi alasan di bukanya cabang PT. Adira Dinamika multi Finance Tbk di kota Jember.

Perkembang dari segi permintaan maupun munculnya competitor membuat perusahaan memutuskan untuk membuka kantor perwakilan di setiap wilayah. Tinjauan Pustaka Loyalitas kepuasan Nasabah menjadi tujuan bagi perencanaan pasar strategik yang dijadikan proses pengembangan keunggulan kompetitif yang berkelanjutan. Dalam lingkungan persaingan global yang semakin ketat dengan masuknya produk-produk pesaing yang lebih inovatif ke dalam pasar dan dengan adanya bentuk kondisi pasar yang jenuh terhadap produkproduk tertentu, maka tugas mengelola tingkay loyalitas kepuasan nasabah menjadi tantangan manajerial yang tidak ringan.

\section{Loyalitas Nasabah}

Suatu nilai kepuasan nasabah menjadi tujuan bagi perusahaan, strategi pengembangan dalam keunggulan kompetitif yang berkelanjutan di lingkungan persaingan global yang semakin ketat dan masuknya produkproduk inovatif ke dalam pasar, dengan kondisi pasar yang jenuh untuk produkproduk tertentu, maka tugas perusahaan dalam menciptakan loyalitas kepuasaan nasabah menjadi tantangan manajerial yang tidak ringan.

Menurut pendapat Kotler dan Keller (2012) bahwa kepuasan loyalitas pelanggan merupakan situasi secara konsisten dalam membelanjakan seluruh anggaran yang ada untuk membeli produk suatu layanan jasa dari penjual yang sama." kepuasan nasabah terhadap salah satu merek, merupakan salah satu nilai tambah sebuah kepuasan loyalitas konsumen, karena untuk membangunnya dipengaruhi banyak tantangan yang harus dihadapi serta membutuhkan waktu yang sangat lama. Lebih lanjut dijelaskan bahwa loyalitas nasabah bagi perusahaan antara lain :

1. Mengurangi biaya pemasaran. Dengan di perolehnya nasabah setia oleh perusahaan, maka hal ini dapat mengurangi jenis biaya pemasaran. Beberapa penelitian menunjukkan bahwa biaya untuk mendapatkan nasabah baru perusahaan harus mengeluatkan biaya enam kali lebih besar dibandingkan dengan biaya untuk mempertahankan nasabah yang ada. Diantaranya biaya iklan dan bentuk-bentuk promosi lainnya yang dilakukan oleh perusahaan dalam jumlah besar, akan tetapi hal ini belum dapat menarik minat nasabah baru, karena tidak gampang membentuk sikap positif terhadap merek.

2. Trade leverage. Pemilihan jenis produk oleh nasabah terhadap merek tertentu merupakan trade leverage bagi perusahaan. Sebuah produk dengan merek yang digemari oleh nasabah akan dapat menarik para distributor untuk memberikan ruang yang lebih besar dibandingkan dengan merek lain. Merek yang memiliki nilai kualitas tinggi, akan mudah untuk menarik minat konsumen, dan konsumen dapat membeli secara berulang- 
ulang dengan merek yang sama bahkan dapat memberikan informasi terhadap konsumen lain.

3. Menarik nasabah baru. Nasabah yang puas dengan suatu jenis merek yang dibelinya, maka hal ini dapat memengaruhi konsumen lain. Nasabah yang tidak puas akan menyampaikan ketidakpuasannya kepada konsumen baru. Dan Sebaliknya, jika konsumen merasa puas akan dapat merekomendasikan kepada orang lain untuk memilih produk yang telah memberikan suatu kepuasan.

4. Merespon ancaman pesaing. Kepuasan nasabah terhadap suatu jenis merek dapat dijadikan gambaran oleh perusahaan untuk merespon tindakan-tindakan yang dilakukan oleh pesaing. Jika pesaing mengembangkan produk yang lebih superior, maka perusahaan memiliki kesempatan untuk membuat produk yang lebih baik dalam jangka waktu tertentu, karena pesaing relatif sulit untuk memengaruhi nasabah-nasabah yang setia. Dikarenakan membutuhkan waktu yang relatif lama. Pentingnya loyalitas kepuasan nasabah terhadap merek dianggap sebagai aset perusahaan dan berdampak besar terhadap pangsa pasar serta profitabilitas perusahaan.

5. Nilai kumulatif bisnis berkelanjutan. Upaya mempertahankan (retensi) nilai kepusaan nasabah yang mempunyai daya beli tinggi pada produk perusahaan sepanjang customer lifetime value, dengan cara menyediakan produk yang konstan, perusahaan dapat melakukannya melalui proses secara teratur dengan harga per unit yang lebih rendah.
6. Word of mouth communication. Nasabah yang memiliki kepuasan terhadap jenis atau merk produk tertentu akan dapat memberikan nilai yang positif (positive word of mouth) tentang perusahaan dan produknya dan dapat mempengaruhi orang lain, teman dan keluarga, ini merupakan tindakan konsumen yang lebih persuasif dari pada iklan atau promosi perusahan.

\section{Kepuasan}

Kotler dalam Tjiptono (2011) menyatakan bahwa kepuasan pelanggan adalah tingkat dari perasaan seseorang setelah membandingkan kinerja (hasil) perusahaan dengan harapan yang dapat diterima oleh pelanggan. Jadi tingkat kepuasan pelanggan merupakan fungsi dari perbedaan antara kinerja yang dirasakan dengan harapan. Apabila kinerja dibawah harapan maka pelanggan akan kecewa tetapi bila kinerja sesuai atau melebihi harapan, maka pelanggan akan merasa puas.

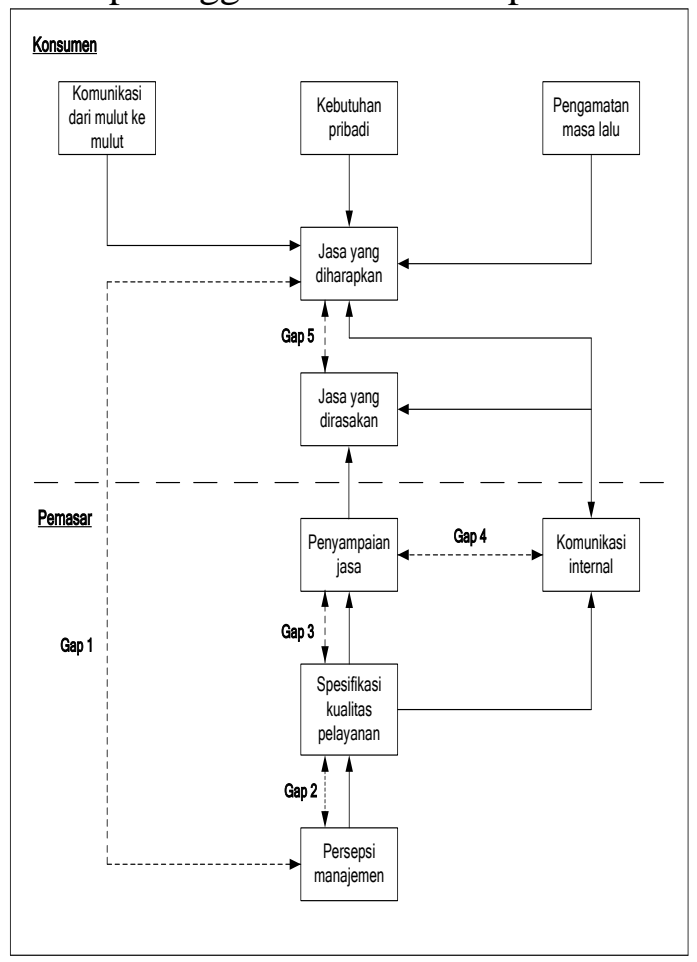

Gambar 1. Model Kualitas Jasa 
Parasuraman, Zeithaml dan Berry dalam Tjiptono (2011) mengidentifikasikan lima gap yang menyebabkan kegagalan penyampaian jasa karena tidak terpenuhinya apa yang diharapkan oleh konsumen, sehingga kepuasan konsumen tidak tercapai. Lima gap itu antara lain :

1. Gap antara harapan konsumen dengan persepsi manajemen

Manajemen tidak selalu memahami dan merasakan dengan apa yang diinginkan oleh para pelanggan secara benar.

2. Gap antara persepsi manajemen dan spesifikasi kualitas jasa

Manajemen perusahaan mungkin sudah benar dalam memahami apa yang diinginkan pelanggan, tetapi belum dapat menemukan standar pelaksanaan yang spesifik.

3. Gap antara spesifikasi kualitas jasa dan penyampaian jasa

Para personil perusahaan mungkin tidak terlatih secara baik dan benar sehingga tidak mampu memenuhi standar yang diinginkan oleh konsumen.

4. Gap antara penyampaian jasa dan komunikasi eksternal

Harapan perusahaan bahwa konsumen dapat dipengaruhi oleh pernyataan yang dibuat oleh perusahaan melalui promosi dan iklan perusahaan.

5. Gap antara jasa yang dialami dengan jasa yang diharapkan

Hal ini terjadi apabila konsumen mengukur kinerja perusahaan dengan pandangan yang berbeda dan memiliki persepsi yang keliru mengenai kualitas jasa yang telah dilakukan oleh perusahaan.

\section{Customer Relationship Management (CRM)}

Menurut Amstrong (2007),

Customer Relationship Management adalah seluruh proses dalam membangun dan menjaga hubungan yang menguntungkan dengan pelanggan melalui pengantaran nilai (value) dan kepuasan (satisfaction) yang tinggi bagi pelanggan. Menurut Amstrong (2007) ini mencakup seluruh aspek dalam mendapatkan nasabah juga peningkatan jumlah pelanggan.

Metagroup pada tahun 2000 (Peelen, 2005), mendefinisikan CRM sebagai proses bisnis horisontal yang terintegrasi termasuk didalamnya front office customer contact points (pemasaran, penjualan, layanan, dan support) melalui berbagai macam saluran penghubung. Menurut Peelen (2005), dalam deskripsi ini, CRM diposisikan dalam sudut Teknologi Informasi yang akurat. Teknologi dapat dijadikan fasilitator dalam terselenggaranya hubungan antara pelanggan dengan karyawan dari berbagai departemen melalui teknologi, dan informasi melalui sarana telekomunikasi juga tentunya dapat menjalin hubungan secara langsung dengan kosumen.

Menurut Buttle dalam agustiyadi (2008), CRM adalah strategi inti dalam bisnis yang mengintegrasikan prosesproses dan fungsi-fungsi internal dengan semua jaringan eksternal untuk menciptakan dan mewujudkan nilai bagi para konsumen secara menguntungkan. CRM didukung oleh data konsumen berkualitas dan teknologi informasi. Menurut Buttle dalam agustiyadi (2008) definisi ini tentunya digunakan dalam konteks perusahaan atau organisasi yang berorientasi profit. Jika komunitas nonprofit (nirlaba) dapat mengubah kata 'bisnis', 'konsumen', dan 'profit' dengan istilah lain yang tepat maka definisi tersebut pasti juga sesuai untuk konteks kerja mereka. 
Customer Value (nilai pelanggan).

Zeithaml

(Tjiptono,2005),

memberikan definisi atau pengertian customer value (nilai pelanggan) sebagai penilaian keseluruhan konsumen terhadap utilitas sebuah produk berdasarkan persepsinya terhadap apa yang diterima dan apa yang diberikan perusahaan terhadap konsumen. Goostain (Tjiptono, 2005) memberikan definisi customer value (nilai pelanggan) adalah ikatan emosional yang terjalin antara pelanggan dan produsen apabila pelanggan sudah menggunakan produk dan jasa dari perusahaan dan mendapati produk atau jasa tersebut yang dapat memberikan nilai tambah. Kotler (Hurriyanti, 2005) memberikan definisi atau pengertian customer value (nilai pelanggan) sebagai selisih dari nilai pelanggan total, artinya nilai pelanggan total adalah sekumpulan manfaat yang diharapkan oleh pelanggan dari produk atau jasa perusahaan serta biaya pelanggan total adalah sekumpulan biaya yang diharapkan oleh konsumen untuk mengevaluasi guna mendapatkan produk atau jasa.

\section{Kepercayaan}

Konsep kepercayaan pelanggan yang digunakan sebagai sarana penelitian ini juga sebagai landasan untuk memahami konsep dan indikator pengukuran kepercayaan dan kepuasan pelanggan. Mancintosh and Lockskin dalam Agustiadi (2008) mengemukakan definisi kepercayaan pelanggan :"define trust as one party's confidence in an exchangepartner's reliability and integrity". Definisi kepercayaan pelanggan tersebut, menunjukan bahwa salah satu pihak percaya dan meyakini kehandalan integritas partner dalam pertukaran.

$$
\text { Lau dan Lee }
$$
mengembangkan konsep kepercayaan pelanggan pada merek tertentu (brand in a trust) dimana "brand trust didefinisikan sebagai kesediaan pelanggan untuk mempercayai dan memiliki suatu produk dalam situasi risiko tinggi karena adanya harapan bahwa merek tersebut memberikan hasil positif bagi perusahaan ".Kepercayaan pelanggan pada salah satu merek dapat dikaitkan dengan kesediaan pelanggan menerima risiko dengan harapan pelanggan akan memperoleh nilai sesuai apa yang di harapkannya.

\section{METODE PENELITIAN}

Penelitian ini mengambil objek nasabah PT Adira Finance Jember. Sedangkan waktu penelitian pada bulan September sampai dengan Desember 2018. Populasi dalam penelitian ini adalah seluruh nasabah PT Adira Finance Jember. Jumlah sampel pada penelitian ini mengacu pada pendapat Sugiyono (2008) bahwa jumlah sampel minimal 10 kali dari jumlah variabel yang dinilai. Dalam penelitian ini variabel yang digunakan sebanyak 5 variabel, yaitu CRM, customer value, kepercayaan, kepuasan nasabah dan loyalitas nasabah. Dengan demikian sampel yang akan diambil dalam penelitian ini berjumlah 50 responden. Kriteria utama pemilihan sampel di dalam penelitian ini adalah nasabah PT Adira Finance Jember. Metode penentuan sampel yang digunakan dalam penelitian ini adalah accidental sampling, dengan alasan jumlah populasi yang terlalu besar. Metode accidental sampling melakukan pengambilan sampel secara acak tanpa memperhatikan kriteria sampel apapun sampai jumlah responden yang diinginkan terpenuhi.

Penelitian ini menggunakan tipe penelitian deskriptif dengan pendekatan kuantitatif. Metode Penelitian Kuantitatif Menurut Sugiyono (2008) Metode penelitian yang berdasarkan pada filsafat 
positivisme, digunakan untuk mengetahui jumlah populasi atau sampel tertentu. Pengumpulan data dengan menggunakan data instrumen penelitian, analisis data bersifat kuantitatif/statistik, dengan tujuan untuk menguji hipotesis yang telah ditetapkan. Identifikasi variabel meliputi Variabel Terikat (loyalitas nasabah), Variabel Interving (kepuasan nasabah) dan Variabel Bebas (CRM, customer value dan kepercayaan)

Metode Analisis Data

A. Uji Instrumen terdiru dari Uji Validitas dan Uji Reliabilitas

B. Uji Ekonometrik (Asumsi Klasik)
1). Uji Normalitas
2). Uji Multikolinearitas
3). Uji Heteroskedastisitas
4). Uji Autokorelasi

C. Analisis Jalur

HASIL DAN PEMBAHASAN

Pengujian Instrumen

\section{Uji Validitas}

\section{Tabel 1. Hasil Uji Validitas}

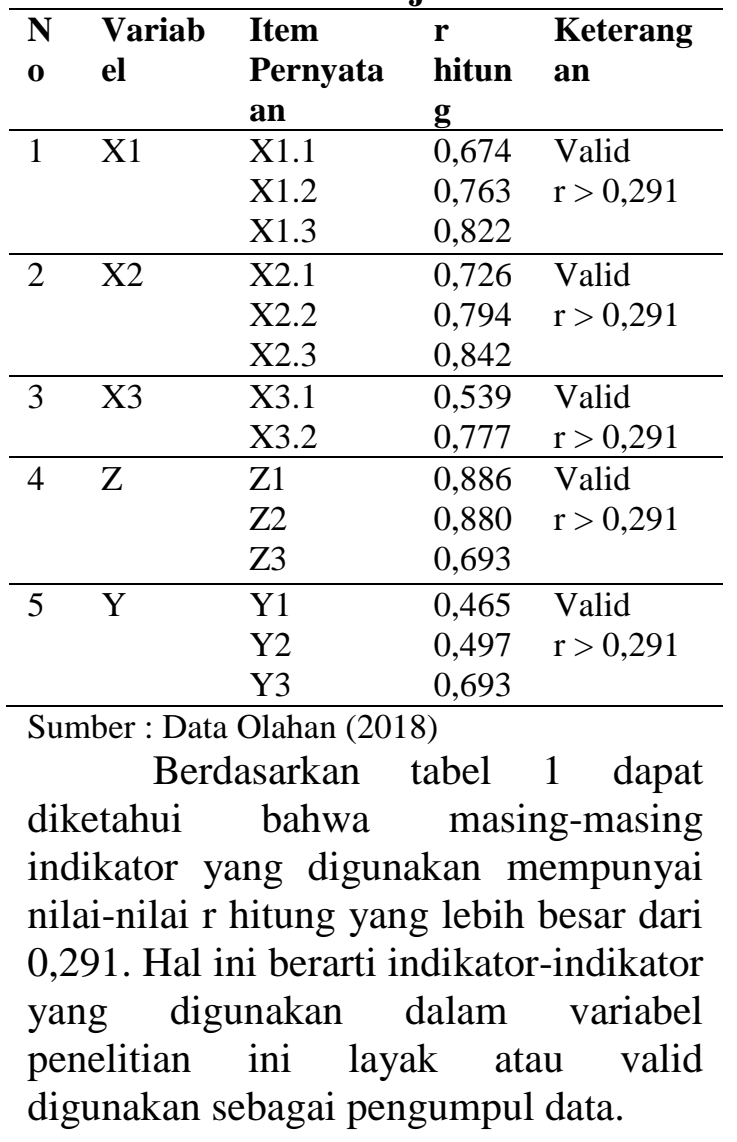

Tabel 2. Hasil Uji Reliabilitas

\begin{tabular}{lllll}
\hline No & Variabel & $\begin{array}{l}\text { Nilai } \\
\text { Alpha }(\alpha)\end{array}$ & Keterangan & \\
\hline 1 & X1 & 0,714 & $\begin{array}{l}\text { Reliabel } \\
0,60\end{array}$ & $>$ \\
\hline 2 & X2 & 0,628 & $\begin{array}{l}\text { Reliabel } \\
0,60\end{array}$ & $>$ \\
\hline 3 & X3 & 0,836 & $\begin{array}{l}\text { Reliabel } \\
0,60\end{array}$ & $>$ \\
\hline 4 & Z & 0,647 & $\begin{array}{l}\text { Reliabel } \\
0,60\end{array}$ & $>$ \\
& & & $\begin{array}{l}\text { Reliabel } \\
0,60\end{array}$ & $>$ \\
\hline 5 & Y & 0,751 & &
\end{tabular}

Sumber : Data Olahan (2018)

Berdasarkan tabel 2 diatas, menunjukkan hasi koefisien keandalan reliabilitas untuk variable $\mathrm{X} 1, \mathrm{X} 2, \mathrm{X} 3$, $\mathrm{Z}$ dan $\mathrm{Y}$ dalam anallisis berada pada kreteria tinggi dan sangat tinggi. Hal ini berarti bahwa item pernyataan yang digunakan akan mampu memperoleh data yang konsisten yang artinya bahwa apabila pertanyaan tersebut diajukan berulang akan diperoleh jawaban yang relative sama dengan jawaban pertama. Sehingga dapat dikatakan bahwa semua variable adalah reliable karena nilai koefisien reliable lebih besar dari 0,6.

\section{Uji Asumsi Klasik}

(1). Uji Normalitas

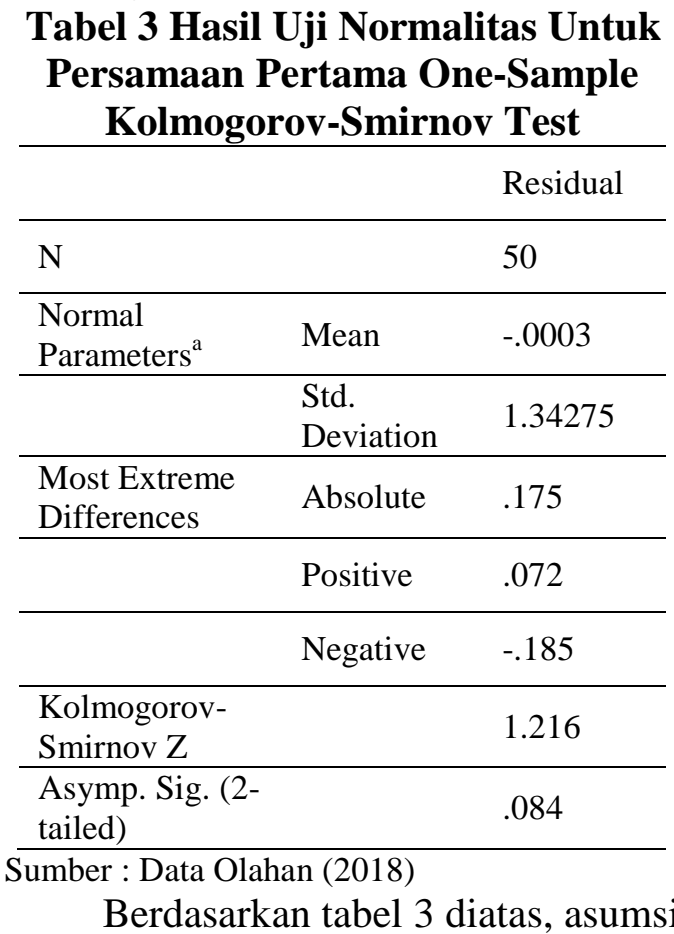

kenornalan nilai residual pada model 1 
perlu diuji untuk membuktikan apakah nilai residual berada disekitar nilai nol. Hasil uji dengan kolmogrov-Smirnov membuktikan bahwa nilai residual pada model 1 mengikuti sebaran normal. Hal ini dibuktikan dengan hasil Asymp.(2tailed) $>0,05$ Nilai residual yang diperoleh adalah 0,084 karena nilai residual untuk 2 tailed $>0,05$ sehingga data dapat dikatakan memenuhi asumsi normalitas karena nilainya $>0,05$.

Tabel 4. Hasil Normalitas Untuk Persamaan Kedua One-Sample Kolmogorov-Smirnov Test

\begin{tabular}{lll} 
& & Residual \\
\hline $\mathrm{N}$ & & 50 \\
\hline $\begin{array}{l}\text { Normal } \\
\text { Parameters }\end{array}$ & Mean & .0177 \\
\hline & $\begin{array}{l}\text { Std. } \\
\text { Deviation }\end{array}$ & 1.28751 \\
\hline $\begin{array}{l}\text { Most Extreme } \\
\text { Differences }\end{array}$ & Absolute & .059 \\
\hline & Positive & .067 \\
\hline $\begin{array}{l}\text { Kolmogorov- } \\
\text { Smirnov Z }\end{array}$ & Negative & -.089 \\
\hline $\begin{array}{l}\text { Asymp. Sig. } \\
\text { (2-tailed) }\end{array}$ & .721 \\
\hline $\begin{array}{l}\text { Sumber : Data Olahan (2018) } \\
\text { Berdasarkan tabel 4 }\end{array}$ & .729 \\
\hline
\end{tabular}

Berdasarkan tabel 4 diatas, asumsi kenornalan nilai residual pada model 2 perlu diuji untuk membuktikan apakah nilai residual berada disekitar nilai nol. Hasil uji dengan kolmogrov-Smirnov membuktikan bahwa nilai residual pada model 1 mengikuti sebaran normal. Hal ini dibuktikan dengan hasil Asymp.(2tailed) $>0,05$. Nilai residual yang diperoleh adalah 0,729 karena nilai residual untuk 2 tailed $>0,05$ sehingga data dapat dikatakan memenuhi asumsi normalitas karena nilainya $>0,05$.

\section{Analisis Jalur (Path Analysis)}

1. Pengaruh Variabel Customer relationship managemen (X1) terhadap kepuasan nasabah (Z) Berdasarkan tabel dapat dilihat nilai beta $(\beta)$, t-hitung dan signifikansi tnya. Perhitungan dengan analisis jalur (path analysis) pada tingkat kepercayaan 5\%, diperoleh nilai beta $(\beta)$ sebesar 0,186 dengan signifikansi $\mathrm{t}$ sebesar 0,035. Karena nilai signifikansi $\mathrm{t}<\alpha$ atau $0,035<0,05$ maka hipotesis tersebut ditolak. Dengan demikian ada pengaruh signifikan customer relationship managemen terhadap kepuasan nasabah. Menurut Buttle dalam agustiyadi (2008), CRM adalah strategi inti dalam bisnis yang mengintegrasikan proses-proses dan fungsi-fungsi internal dengan semua jaringan eksternal untuk menciptakan dan mewujudkan nilai bagi para konsumen secara menguntungkan.

2. Pengaruh Variabel Customer value (X2) terhadap kepuasan nasabah (Z) Berdasarkan tabel dapat dilihat nilai beta $(\beta)$, t-hitung dan signifikansi tnya. Perhitungan dengan analisis jalur (path analysis) pada tingkat kepercayaan 5\%, diperoleh nilai beta $(\beta)$ sebesar 0,784 dengan signifikansi $\mathrm{t}$ sebesar 0,000. Karena nilai signifikansi $\mathrm{t}<\alpha$ atau $0,000<0,05$ maka hipotesis tersebut ditolak. Dengan demikian ada pengaruh signifikan customer value terhadap kepuasan nasabah. . Goostain (Tjiptono, 2005) memberikan definisi customer value (nilai pelanggan) adalah ikatan emosional yang terjalin antara pelanggan dan produsen apabila pelanggan sudah menggunakan produk dan jasa dari perusahaan dan mendapati produk atau jasa tersebut yang dapat memberikan nilai tambah. Untuk itu semakin bagus nilai pelanggan yang dihasilkan maka akan menambah kepuasan pelanggan.

3. Pengaruh Variabel Kepercayaan (X3) terhadap kepuasan nasabah (Z) Berdasarkan tabel dapat dilihat nilai beta $(\beta)$, t-hitung dan signifikansi 
tnya. Perhitungan dengan analisis jalur (path analysis) pada tingkat kepercayaan 5\%, diperoleh nilai beta $(\beta)$ sebesar 0,165 dengan signifikansi $t$ sebesar 0,007. Karena nilai signifikansi $\mathrm{t}>\alpha$ atau $0,007<0,05$ maka hipotesis tersebut ditolak. Dengan demikian ada pengaruh signifikan kepercayaan terhadap kepuasan nasabah.

4. Pengaruh Variabel Customer relationship management (X1) terhadap Loyalitas nasabah (Y). Berdasarkan tabel dapat dilihat nilai beta $(\beta)$, t-hitung dan signifikansi tnya. Perhitungan dengan analisis jalur (path analysis) pada tingkat kepercayaan 5\%, diperoleh nilai beta $(\beta)$ sebesar 0,136 dengan signifikansi $t$ sebesar 0,027. Karena nilai signifikansi $\mathrm{t}<\alpha$ atau $0,027<0,05$ maka hipotesis tersebut ditolak. Dengan demikian ada pengaruh signifikan Customer relationship management terhadap loyalitas nasabah.

5. Pengaruh Variabel customer value (X2) terhadap loyalitas nasabah (Y) Berdasarkan tabel dapat dilihat nilai beta $(\beta)$, t-hitung dan signifikansi tnya. Perhitungan dengan analisis jalur (path analysis) pada tingkat kepercayaan $5 \%$, diperoleh nilai beta $(\beta)$ sebesar 0,361 dengan signifikansi $\mathrm{t}$ sebesar 0,032. Karena nilai signifikansi $\mathrm{t}<\alpha$ atau $0,032<0,05$ maka hipotesis tersebut ditolak. Dengan demikian ada pengaruh signifikan customer valeu terhadap loyalitas nasabah.

6. Pengaruh Variabel kepercayaan (X3) terhadap loyalitas nasabah (Y) Berdasarkan tabel dapat dilihat nilai beta $(\beta)$, t-hitung dan signifikansi tnya. Perhitungan dengan analisis jalur (path analysis) pada tingkat kepercayaan 5\%, diperoleh nilai beta $(\beta)$ sebesar 0,641 dengan signifikansi t sebesar 0,000. Karena nilai signifikansi $\mathrm{t}<\alpha$ atau $0,000<0,05$ maka hipotesis tersebut ditolak. Dengan demikian ada pengaruh signifikan kepercayaan terhadap loyalitas nasabah. kepercayaan pelanggan tersebut, menunjukan bahwa salah satu pihak percaya dan meyakini kehandalan integritas partner dalam pertukaran.

7. Pengaruh Variabel kepuasan nasabah (Z) terhadap loyalitas nasabah (Y). Berdasarkan tabel dapat dilihat nilai beta $(\beta)$, thitung dan signifikansi tnya. Perhitungan dengan analisis jalur (path analysis) pada tingkat kepercayaan 5\%, diperoleh nilai beta $(\beta)$ sebesar 0,045 dengan pvalue sebesar 0,042. Karena nilai signifikansi $\mathrm{t}<\alpha$ atau $0,042<0,05$ maka hipotesis tersebut ditolak. Dengan demikian ada pengaruh signifikan kepuasan nasabah terhadap loyalitas nasabah. Hasil penelitian sejalan dengan penelitian oleh Samuel, Hatane \& Foedjiawati (2005) dimana kepuasan memberikan pengaruh positif signifikan terhadap loyalitas.

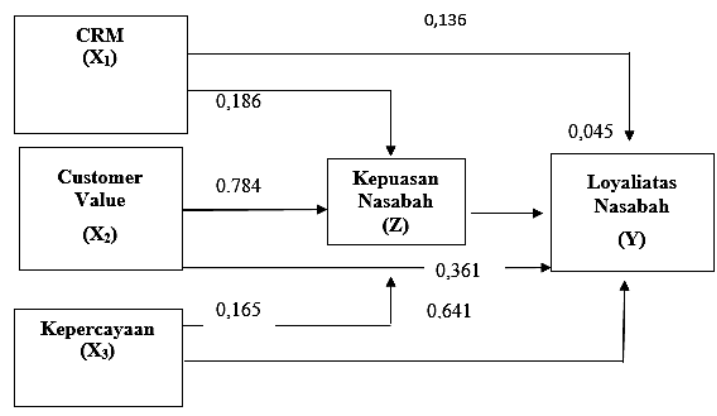

\section{Gambar 2 Hasil Analisis Jalur}

\section{Menghitung Pengaruh Langsung (Direct Effect atau DE)}

Pengaruh variabel customer relationship management (X1) terhadap kepuasan nasabah $(\mathrm{Z})$

DEzx $1=X 1 \quad Z \rightarrow 0,186$ 
Pengaruh variabel customer value (X2) terhadap kepuasan nasabah $(\mathrm{Z})$

DEzx2 $=\mathrm{X} 2 \quad \mathrm{Z} \rightarrow=0,784$

Pengaruh variabel kepercayaan (X3) terhadap kepuasan nasabah $(\mathrm{Z})$

DEzx3 = X3 $\mathrm{Z} \rightarrow=0,165$

Pengaruh variabel customer relationship management (X1) terhadap loyalitas nasabah (Y)

DEyx $1=\mathrm{X} 1 \quad \mathrm{Y} \rightarrow 0,136$

Pengaruh variabel customer value (X2) terhadap loyalitas nasabah (Y)

DEyx2 = X2 Y $\rightarrow 0,361$

Pengaruh variabel kepercayaan (X3) terhadap loyalitas nasabah (Y)

DEyx3 = X3 $\quad \mathrm{Y} \rightarrow 0,641$

Pengaruh variabel kepuasan nasabah (Z) terhadap loyalitas nasabah (Y)

DEyz $=\mathrm{Z} \quad \mathrm{Y} \rightarrow 0,045$

\section{Menghitung pengaruh tidak langsung (Indirect effect atau IE)}

Pengaruh variabel customer relationship management (X1) terhadap loyalitas nasabah (Y) melalui kepuasan nasabah (Z)

IEyzx1 $=\mathrm{X} 1 \quad \mathrm{Z} \rightarrow \mathrm{Y} \rightarrow \quad$ Indirect $; \mathrm{Y}$ $\leftarrow \mathrm{X} 1 \rightarrow \mathrm{Z} \rightarrow \mathrm{Y}=(0,185) \cdot(0,136)=$ $0,025=2,5 \%$

Pengaruh variabel customer value (X2) terhadap loyalitas nasabah (Y) melalui kepuasan nasabah $(\mathrm{Z})$

IEyzx $2=\mathrm{X} 2 \rightarrow \mathrm{Z} \rightarrow \mathrm{Y}$

Indirect; $\mathrm{Y} \leftarrow \mathrm{X} 2 \rightarrow \mathrm{Z} \rightarrow \mathrm{Y}=(0,784)$. $(0,361)=0,283=28,3 \%$

Pengaruh variabel kepercayaan (X3) terhadap loyalitas nasabah (Y) melalui kepuasan nasabah $(\mathrm{Z})$

IEyzx $3=\mathrm{X} 3 \rightarrow \mathrm{Z} \rightarrow \mathrm{Y}$

Indirect $\mathrm{Y} \leftarrow \mathrm{X} 5 \rightarrow \mathrm{Z} \rightarrow \mathrm{Y}=(0,165)$. $(0,641)=0,106=10,6 \%$

\section{Menghitung pengaruh total (Total effect atau TE)}

Pengaruh variabel customer relationship management (X1) terhadap loyalitas nasabah $(\mathrm{Y})=$ pengaruh variabel $\mathrm{X} 1$ terhadap $\mathrm{Y}$ melalui $\mathrm{Z}+$ pengaruh langsung variable $X 1$ terhadap $Y$

TEyzx $1=$ DEyx $1+$ IEyzx 1

$=0,136+0,025=0,161=16,1 \%$

Pengaruh variabel customer value (X2) terhadap loyalitas nasabah (Y) = pengaruh variabel $\mathrm{X} 2$ terhadap $\mathrm{Y}$ melalui $\mathrm{Z}+$ pengaruh langsung variable $\mathrm{X} 2$ terhadap $\mathrm{Y}$

TEyzx 2 = DEyx 2 + IEyzx 2

$=0,361+0,283=0,644=64,4 \%$

Pengaruh variabel kepercayaan (X3) terhadap loyalitas nasabah $(\mathrm{Y})=$ pengaruh variabel $\mathrm{X} 3$ terhadap $\mathrm{Y}$ melalui $\mathrm{Z}+$ pengaruh langsung variable $\mathrm{X} 3$ terhadap Y

TEyzx $5=$ DEyx $5+$ IEyzx $3=0,641+$ $0,106=0,747=74,7 \%$

Tabel 5 Hasil Analisis Koefisien Jalur

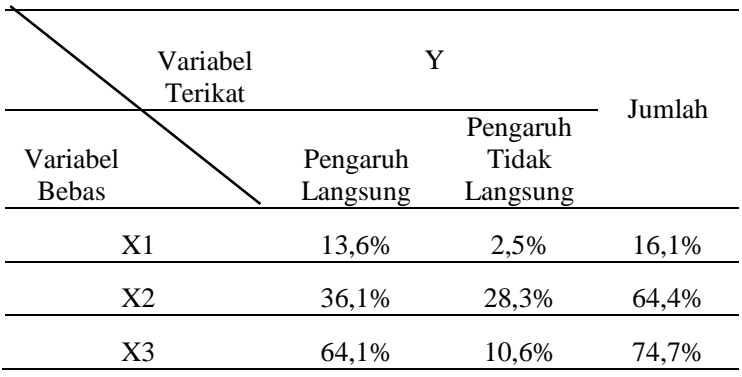

Berdasarkan tabel 5 diatas, hasil perhitungan koefisien jalur, terlihat bahwa total pengaruh variabel customer relationship management (X1) terhadap loyalitas nasabah (Y) adalah $16,1 \%$ dengan rincian pengaruh langsung sebesar $13,6 \%$ dan pengaruh tidak langsung sebesar 2,5\%. Total pengaruh customer value (X2) terhadap loyalitas nasabah (Y) adalah $64,4 \%$ dengan rincian pengaruh langsung sebesar $36,1 \%$ dan pengaruh tidak langsung sebesar 28,3\%. Sedangkan total kepercayaan (X3) terhadap loyalitas nasabah (Y) adalah $74,7 \%$ dengan rincian pengaruh langsung sebesar $64,1 \%$ dan pengaruh tidak langsung sebesar $10,6 \%$. 


\section{PENUTUP}

\section{Kesimpulan}

1. Customer

Relationship

Management (CRM), customer value, kepercayaan berpengaruh secara langsung terhadap kepuasan nasabah PT Adira Finance Jember Customer Relationship Management (CRM), customer value dan kepercayaan berpengaruh secara langsung dan tidak langsung terhadap loyalitas melalui kepuasan nasabah PT Adira Finance Jember

2. Variabel kepercayaan

merupakan variable dengan total pengaruh terbesar terhadap loyalitas nasabah (Y) PT Adira Finance Jember

\section{Saran}

1. Untuk meningkatkan pengaruh variabel customer relationship management terhadap kepuasan nasabah, perusahaan dapat memberikan pelatihan pada karyawan akan pelayanan prima

2. Untuk meningkatkan pengaruh variabel Customer value terhadap kepuasan nasabah, perusahaan dapat memberikan nilai lebih pada pelanggan melalui bonus.

3. Untuk meningkatkan pengaruh variabel Kepercayaan terhadap kepuasan nasabah, perusahaan dapat meyakinkan pelanggan akan kehandalan dan integritas perusahaan.

4. Untuk meningkatkan pengaruh variabel Customer relationship management terhadap Loyalitas nasabah, perusahaan dapat memberikan pelayan terbaik.

5. Untuk meningkatkan pengaruh variabel customer value terhadap loyalitas nasabah, perusahaan dapat membuat member sebagai ikatan emosional yang terjalin antara pelanggan dan produsen setelah pelanggan menggunakan produk dan jasa

6. Untuk meningkatkan pengaruh variabel kepercayaan terhadap loyalitas nasabah, perusahaan dapat memberikan kepastain kualitas produk

7. Untuk meningkatkan pengaruh variabel kepuasan nasabah terhadap loyalitas nasabah, perusahaan dapat memberikan kualitas yang baik agar pelangan puas

\section{DAFTAR PUSTAKA}

Amstrong. (2007). Customer Relationship Management

Agustiyadi M, Tri. (2008). Pentingnya Customer Relationship Management untuk Meningkatkan Loyalitas Pelanggan

Hurriyati, Ratih. (2005). Bauran Pemasaran dan Loyalitas Konsumen, Bandung Alfabeta

Kotler, Philip dan Kevin Lane Keller. (2012). Marketing Management. Essex: Pearson Education Inc.

Lau, G. T. \& Lee S. H. (1999). "Consumers Trust in a Brand and The Link to Brand Loyalty". Journal of Market Focused Management, 341-370.

Peelen, E. (2005).Customer Relationship Management. Prentice-Hall, England

Sugiyono. (2008). Metode Penelitian Bisnis. Bandung: Alfabeta

Samuel, Hatane \& Foedjiawati. (2005). Pengaruh kepuasan konsumen terhadap kesetiaan merek (Studi Kasus Restoran The Prime Steak \& Ribs Surabaya). Jurnal Ekonomi Manajemen, FE Universitas Kristen Petra, Surabaya.

Tjiptono, Fandy. (2005). Brand Management \&Strategy. Yogyakarta: ANDI.

Tjiptono, Fandy. (2011). Pemasaran Jasa, Bayumedia, Malang 